\title{
Acral enlargement without growth hormone excess: a clinical conundrum
}

\author{
Sandeep Agarwal, Riddhi Dasgupta, ${ }^{\ominus}$ Thomas Vizhalil Paul, Nihal Thomas
}

Department of Endocrinology, Diabetes and Metabolism, Christian Medical College and Hospital, Vellore, Tamil Nadu, India

\section{Correspondence to} Dr Riddhi Dasgupta, riddhi_dg@rediffmail.com

Accepted 27 March 2019

Check for updates

(c) BMJ Publishing Group Limited 2019. No commercial re-use. See rights and permissions. Published by BMJ.

To cite: Agarwal $S$, Dasgupta R, Paul TV, et al. BMJ Case Rep 2019;12:e229046 doi:10.1136/bcr-2018229046

\section{DESCRIPTION}

Pachydermoperiostosis (Touraine-Solente-Golé Syndrome) is a hereditary disorder which usually presents with bony lesions (periostosis), digital clubbing and skin thickening (pachyderma). Facial coarsening, spade-like hands and feet with increased sweating may cause diagnostic confusion between acromegaly and pachydermoperiostosis. We report a case of an 18-year-old man who presented with progressive enlargement of hands and feet, increased sweating of palms and sole and drooping of eyelids since birth. Family history of similar illness was present in his maternal aunt and grandfather. Pachydermoperiostosis was suspected and evaluated further by hormonal workup and radiological studies. We made a diagnosis of complete (classic) pachydermoperiostosis based on the findings of normal insulin- like growth factor-1, hyperhydrosis, blepharoptosis, skin thickening, digital clubbing and prominent radiological abnormalities.

An 18-year-old man, resident of Jharkhand, India, presented with chief complaints of progressive disproportionate enlargement and excessive sweating of hands and feet since birth (figure 1A,B). $\mathrm{He}$ was born out of a non-consanguinous marriage at term with a birth weight of $2.6 \mathrm{~kg}$. The antenatal and perinatal periods were uneventful. His developmental milestones and scholastic performances were normal. He did not give any history of palpitations, heat intolerance, weight loss or hyperdefecation. Neither were there any history of headache, visual disturbances or other features of anterior pituitary hormone insufficiency. However, there was family history of similar enlargement hands and feet in his maternal aunt and maternal grandfather.

On examination, he was normotensive with a height of $163 \mathrm{~cm}$ (height SD -2.1 , mid parental height of $166.5 \mathrm{~cm}$ ), weight of $54 \mathrm{kgs}$ (5th-10th centile) and upper segment:lower segment ratio of 0.87 . He had normal secondary sexual characteristics with a Tanner's staging of G4, P4 and A+. His hands and feet were enlarged with bilateral

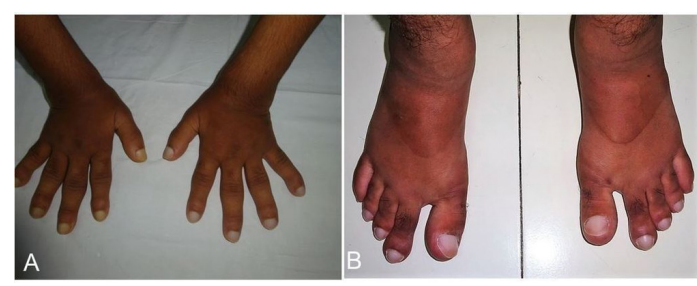

Figure 1 ( $A$ and $B$ ) Showing excessive soft tissue in hand and feet with clubbing. knee swellings. He had hyperhidrosis of both palms and soles with bilateral fine tremor. He had no prognathism but had malalingment of teeth. There was no goitre or gynaecomastia. He also had slight drooping of both eyelids and a bulbous nose (figure 2). Grade 4 clubbing was present in both hands and feet (figure 1A, B).

Systemic examination was essentially normal. Further investigations revealed the presence of mild iron deficiency anaemia without any other peripheral blood count abnormalities. He had normal liver function tests, serum creatinine and electrolytes; hormonal evaluation revealed thyroid stimulating hormone levels of $3.2 \mathrm{mIU} / \mathrm{L}(\mathrm{N}=0.3-4.5)$ with total $\mathrm{T} 4=10.2 \mu \mathrm{g} / \mathrm{dL}(\mathrm{N}=4-12)$ and free $\mathrm{T} 4=1.19$ $\mathrm{ng} / \mathrm{dL} \quad(\mathrm{N}=0.8-1.8)$. The Insulin-like Growth Factor(IGF)-1-210 ng/mL (normal range, 109-527) levels were normal with suppression of growth hormone after $75 \mathrm{~g}$ oral glucose to $0.12 \mathrm{ng} / \mathrm{mL}$ (normal <0.4). Serological workup for connective tissue diseases and vasculitis was negative, while there was presence of vitamin D deficiency $(25-\mathrm{OH}$ vitamin $\mathrm{D}=9.6 \mathrm{ng} / \mathrm{mL}$, normal >30). Radiological evaluation of long bones was suggestive of periostitis mainly in the diaphyseal region (figure 3). X-ray of both hands and feet were suggestive of extensive soft tissue enlargement and evidence of periostitis and acro-osteolysis (figure 4A, B). While a normal upper gastrointestinal (GI) endoscopy ruled out the possibility of gastric ulcerations or erosions leading to blood loss, cardiopulmonary causes for the condition were excluded based on normal investigations including an ECG, echocardiogram, arterial blood gas analysis, chest X-ray and pulmonary function tests. Based on these clinical, biochemical and radiological findings, a diagnosis of classic (complete) pachydermoperiostosis with mild iron deficiency anaemia of nutritional aetiology was made.

Pachydermoperiostosis was first described by Friedreich in 1868, ${ }^{1}$ who called it 'Hyperostosis of the entire skeleton'. The estimated prevalence of the disease is $0.16 \% \%^{2}$ with symptoms usually appearing around puberty, with a male to female ratio of $7: 1^{3}$ and severely affects men. Although an autosomal dominant model with incomplete penetrance and variable expression being proved, ${ }^{4}$ both autosomal recessive and X-linked inheritance patterns have been suggested. An infantile form has also been described ${ }^{5}$ which is characterised by early presentation with enlargement and delayed closure of the cranial sutures, patent arterial duct and skin manifestations. This condition progresses slowly for a few years and is self-limiting thereafter. 


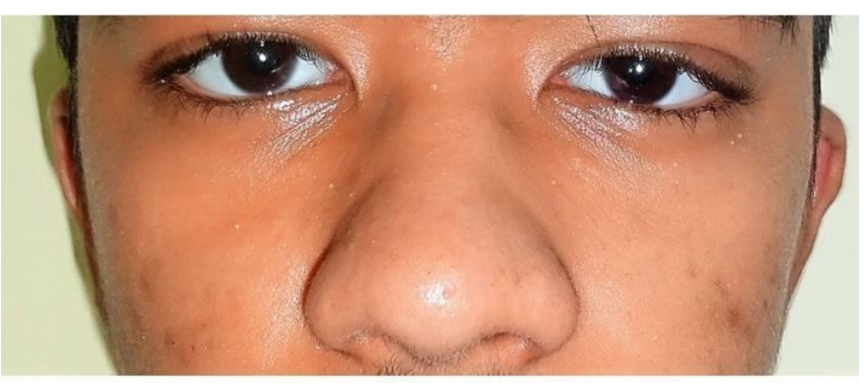

Figure 2 Showing slight drooping of both eyelid and bulbous nose.

This disease may present in three forms: classic or complete (skin thickening, skeletal changes and digital clubbing), incomplete (skeletal changes without involvement of skin) and forme fruste (skin thickening with minimal skeletal change). The major criteria includes periostosis, pachyderma and digital clubbing. ${ }^{6}$ The minor criteria mentioned in the literature are blepharoptosis, hyperhidrosis, arthralgia, seborrhea, joint effusion, gastric ulcer, cutis verticis gyrate, flushing oedema, acne, column like legs. Our patient had three major criteria (digital clubbing, bony changes on skeletal radiograph and skin thickening) and three minor criteria (joint effusion, sweating and blepharoptosis) which was sufficient to label him as a case of complete(classic) pachydermoperiostosis. The exact cause is unknown but recently mutations in $15-\mathrm{OH}$ prostaglandin dehydrogenase on chromosome $4 \mathrm{q} 34.1$ has been suggested as the possible aetiology. ${ }^{7}$ Genetic analysis was planned in our case, but could not be performed due to financial constraints of the patient.

As the patient did not complain of any visual symptoms or cosmetic concerns regarding drooping of the eyelids, active intervention was deferred and patient was advised to follow-up periodically. Differential diagnosis for this rare condition includes syphilitic periostitis, thyroid acropachy, acromegaly,
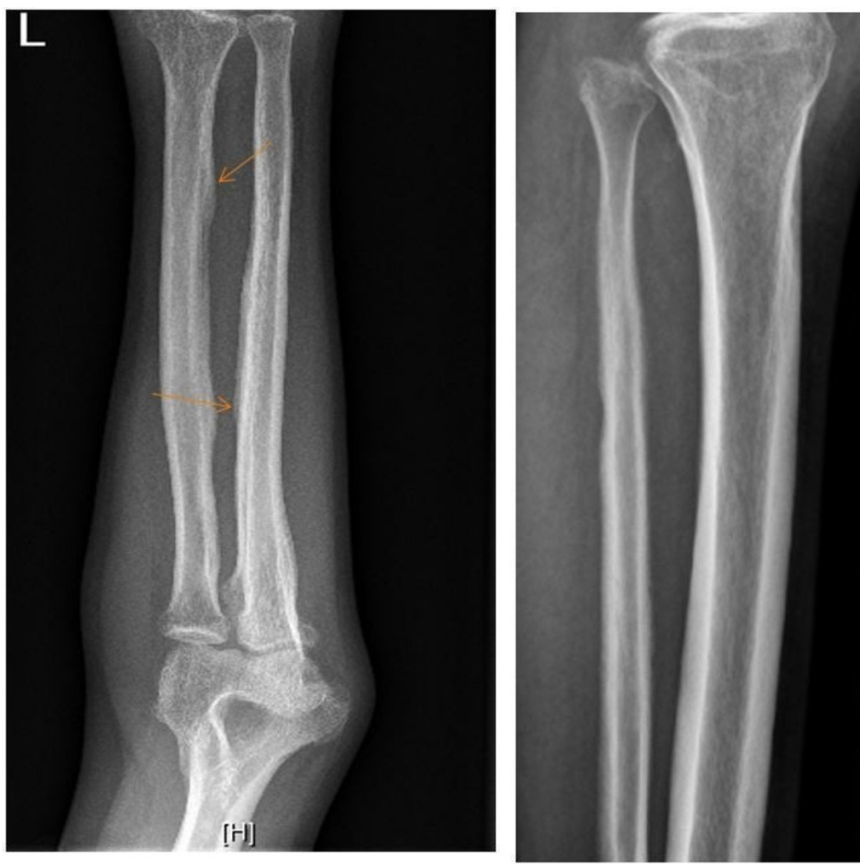

Figure 3 Long bones showing periosteal thickening mainly in the diaphyseal region (arrows).

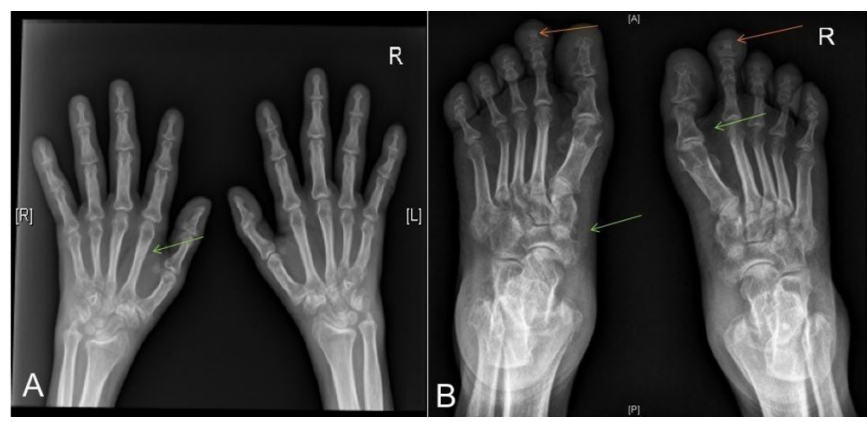

Figure 4 ( $A$ and $B$ ) Showing excessive soft tissue in hand and feet with evidence of periostitis (green arrow) and acro-osteolysis (first and second toe, orange arrow).

Van Buchem's disease, diaphyseal dysplasia, secondary hypertrophic osteoarthropathy and chronic inflammatory rheumatic diseases.

A range of benign and malignant disorders ${ }^{8}$ have been reported in association with pachydermoperiostosis. These include facial epidermoid carcinoma, hypertrophic gastritis, peptic ulcer, gastric adenocarcinoma, Crohn's disease and myelofibrosis. As a consequence of increased soft tissue bulk and hyperostosis, complications may arise such as ptosis, compression of the nerve endings, hearing problems, kyphosis, arthrosis, osteonecrosis of the femoral head and carpal tunnel syndrome. Our patient did not have any of these complications. The anaemia seen in these patients can be multifactorial-including myelofibrosis, gastric ulcers and GI bleeding and a possible serum inhibitor of erythropoetin. ${ }^{9}$ None of these were present on investigations in our patient and the iron deficiency anaemia was attributed to nutritional deficiency. He was supplemented with oral iron therapy and planned for follow-up.

No specific treatment is currently available. Medical management ${ }^{10}$ is indicated for symptomatic benefit and it includes non-steroidal anti-inflammatory drugs, colchicine, corticosteroids, retinoids, tricyclic antidepressants, risedronate, pamidronate and tamoxifen citrate to control arthritis. Botulinum toxin-A has also been tried for cosmetic reasons. Surgical management may include correction of bony deformities if any, and plastic surgery for disfigurement. Prognosis for this disease is good and patients have normal life expectancy. Our patient was advised to be on regular follow-up and is currently only on oral iron and vitamin D supplements in view of anaemia and vitamin D deficiency.

\section{Learning points}

- The combination of digital clubbing, pachyderma and periosteitis should warrant consideration of pachydermoperiostosis after a thorough evaluation to rule out cardiopulmonary, hepatic and mediastinal disorders.

- A combination of major and minor clinical features makes the diagnosis more likely, though differentials including thyroid acropachy, acromegaly and rarer causes like Van Buchem's disease need to be carefully considered.

- Family medical history, specially if autosomal dominant, should prompt to think of pachydermoperiostosis rather than acromegaly, though acromegaly can less commonly be familial. 
Contributors All the authors have contributed to the manuscript and declared no conflict of interests. SA and RD have contributed to the data collection, diagnostic workup, review of literature, preliminary writeup and finalising the manuscript for submission. TVP and NT have contributed to the diagnostic workup, review of literature and finalising the manuscript for submission.

Funding The authors have not declared a specific grant for this research from any funding agency in the public, commercial or not-for-profit sectors.

Competing interests None declared.

Patient consent for publication Obtained.

Provenance and peer review Not commissioned; externally peer reviewed.

\section{REFERENCES}

1 Friedreich N. Hyperostose des gesammten Skelettes. Archiv für Pathologische Anatomie und Physiologie und für Klinische Medicin 1868;43:83-7.

2 Jajic I, Jajic Z. Prevalence of primary hypertrophic osteoarthropathy in selected population. Clin Ex Rheum 1992;10:73
3 Martínez-Lavín M. Digital clubbing and hypertrophic osteoarthropathy: a unifying hypothesis. J Rheumatol 1987;14:6-8.

4 Castori M, Sinibaldi L, Mingarelli R, et al. Pachydermoperiostosis: an update. Clin Genet 2005:68:477-86.

5 Reginato AJ, Schiapachasse V, Guerrero R. Familial idiopathic hypertrophic osteoarthropathy and cranial suture defects in children. Skeletal Radiol 1982;8:105-9.

6 Rastogi R, Suma GN, Prakash R, et al. Pachydermoperiostosis or primary hypertrophic osteoarthropathy: A rare clinicoradiologic case. Indian J Radiol Imaging 2009;19:123-6.

7 Fonseca C, Martinez-Lavin M, Hernandez-Rodriguez A. Circulating plasma levels of platelet derived growth factor in patients with hypertrophic osteoarthropathy. Clin Exp Rheumatol 1992;10(suppl 7):72.

8 Bachmeyer C, Blum L, Cadranel JF, et al. Myelofibrosis in a patient with pachydermoperiostosis. Clin Exp Dermatol 2005;30:646-8.

9 Venencie PY, Boffa GA, Delmas PD, et al. Pachydermoperiostosis with gastric hypertrophy, anemia, and increased serum bone Gla-protein levels. Arch Dermatol 1988;124:1831-4.

10 Kabi F, Mkinsi O, Janani S, et al. A case report. J Intern Med 2006;27:710-2.

Copyright 2019 BMJ Publishing Group. All rights reserved. For permission to reuse any of this content visit https://www.bmj.com/company/products-services/rights-and-licensing/permissions/

BMJ Case Report Fellows may re-use this article for personal use and teaching without any further permission.

Become a Fellow of BMJ Case Reports today and you can:

- Submit as many cases as you like

- Enjoy fast sympathetic peer review and rapid publication of accepted articles

- Access all the published articles

- Re-use any of the published material for personal use and teaching without further permission

For information on Institutional Fellowships contact consortiasales@bmjgroup.com

Visit casereports.bmj.com for more articles like this and to become a Fellow 